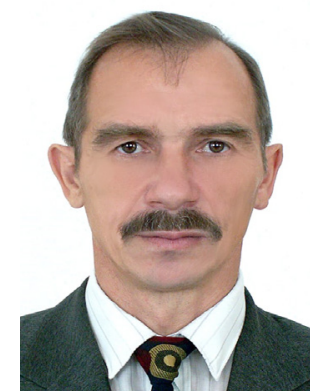

Baxumoв P.I.

Vakhitov R.G.

старший преподаватель, кафедра «Физическое воспитание», факультет общенаучных дисииплин, ФГБОУ ВО «Уфимский государственный нефтяной технический университет», 2. Уфа, Российская Федераџия



Бережнова 3.3.

Berezhnova Z.Z.

старший преподаватель, кафедра «Физическое воспитание», факультет общенаучных дисциплин, ФГБОУ ВО «Уфимский государственный нефтяной технический университет», 2. Уфа, Российская Федераичи

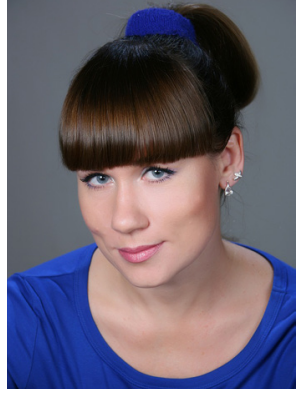

Красулина Н.А.

Krasulina N.A.

кандидат химических наук, дочент, кафедра «Физическое воспитание», факультет общенаучных дисциплин, ФГБОУ ВО «Уфимский государственный нефтяной технический университет», г. Уфа, Российская Федерация

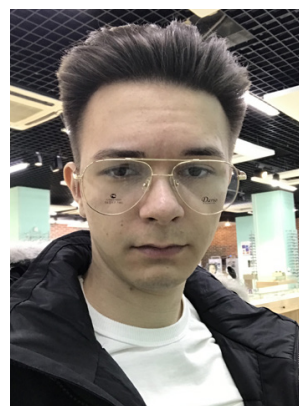

Гареев А.И.

Gareev A.I.

студент кафедры "Сооружения и ремонт газонефтепроводов и газонефтехранилищу», факультет трубопроводного транспорта ФГБОУ ВО «Уфимский государственный нефтяной технический университет», 2. Уфа, Российская Федерачия

DOI: $10.17122 / 2541-8904-2020-3-33-154-160$ \\ ИНТЕГРИРОВАНИЕ КОМПЛЕКСА УПРАЖНЕНИЙ ЦИГУН В МЕТОДЫ ФИЗИЧЕСКОГО ВОСПИТАНИЯ ВЫСШЕГО УЧЕБНОГО ЗАВЕДЕНИЯ
}

Исследовано влияние комплекса традиционных упражнений цигун, используемых совместно с классическими методами занятий физической культурой, с целью выявления тенденции изменения показателей общефизического состояния, мониторинга ряда медицинских анализов (общий анализ крови, биохимический анализ крови, пульс, давление). В работе принимали участием 619 (шестьсот девятнадцать) студентов мужских основных групп, из них 550 человек - экспериментальная группа и 69 - контрольная. Научная работа проведена на базе Уфимского государственного нефтяного технического университета в годовой срок, с 21 сентября 2019 года по 20 февраля 2020 года. Цель данного исследования заключается в изучении влияния данной методики на повышение уровня функционального состояния уча- 
щихся, на совершенствование процесса физического воспитания и воздействие на здоровье студентов УГНТУ, посещающих учебные занятия.

Похожее исследование описали в своих научных публикациях В.В. Винантова (1996) и Л.Р. Калимуллина (2005).

Ю.А. Петрова в своих работах (1992) отметила, что у студентов под действием тренировок увеличивается объем циркулирующей крови, ее компонентов и общего числа гемоглобина.

Метаболизм стоит во главе изменений, проявляющихся в результате выполнения физических нагрузок. Происходит выделение энергии и синтез АТФ, увеличивается скорость катаболических процессов $[1,2]$.

Концентрация форменных элементов крови увеличивается в случае, когда часть плазмы покидает сосудистое русло и уходит в межклеточную жидкость из-за физической нагрузки. Прежде всего это относится к эритроцитам, транспортирующим кислород. В подобных условиях тот же объем крови способен перенести больше кислорода работающим мышцам [3]. Недостатком уменьшения объема плазмы является увеличение вязкости крови, затрудняющее работу сердца.

В конце XIX века было установлено увеличение числа лейкоцитов в крови после занятий физической нагрузкой - миогенный лейкоцитоз. А.П. Егоров в своих работах (1926) показал, что миогенный лейкоцитоз сопровождается увеличением количества белых кровяных телец. Последняя фаза может сопровождаться резким увеличением или же резким уменьшением количества лейкоцитов до физиологии нормы [4]. Изменение уровня лимфоцитов в крови вследствие физической нагрузки может определяться как один из прогностических признаков, показывающих уровень адаптации организма к физическим нагрузкам.

Ключевые слова: цигун, спорт, физическая культура, кровь, анализ, здоровье.

\section{INTEGRATION OF A SET OF QIGONG EXERCISES INTO PHYSICAL EDUCATION METHODS OF A HIGHER EDUCATIONAL INSTITUTION}

The influence of a complex of traditional qigong exercises, used in conjunction with classical methods of physical education, has been investigated in order to identify trends in changes in the indicators of general physical condition, to monitor a number of medical tests (general blood test, biochemical blood test, pulse, pressure). The work involved 619 (six hundred and nineteen) students of male main groups, of which 550 people were the experimental group and 69 were the control group. Scientific work was carried out on the basis of the Ufa State Petroleum Technical University in an annual period, from September 21, 2019 to February 20, 2020. The purpose of this study is to study the influence of this technique on increasing the level of the functional state of students, improving the process of physical education, the impact on the health of USPTU students attending classes.

A similar study was described in his scientific publications by V.V. Vinantova (1996) and L.R. Kalimullina (2005).

Yu.A. Petrova in her works (1992) noted that the volume of circulating blood, its components and the total number of hemoglobin increases in students under the influence of training.

Metabolism is at the forefront of the changes that occur as a result of exercise. Accompanied by the released energy and the synthesis of ATP, the rate of catabolic processes in the body increases $[1,2]$.

The concentration of blood corpuscles increases when part of the plasma leaves the vascular bed and goes into the intercellular fluid due to physical exertion. First of all, this applies to red blood cells that transport oxygen. Under such conditions, the same volume of blood is able to carry more oxygen to working muscles [3]. The disadvantage of reducing plasma volume is an increase in blood viscosity, which makes it difficult for the heart to work.

At the end of the 19th century, an increase in the number of leukocytes in the blood after exercise was found - myogenic leukocytosis. A.P. Egorov in his works (1926) showed that myogenic leukocytosis is accompanied by an increase in the number of white blood cells. The last phase may be accompanied by a sharp increase or a sharp decrease in the number of leukocytes to the physiology

Вестник УГНТУ. Наука, образование, экономика. Серия экономика. № 3 (33), 2020 
of the norm [4]. A change in the level of lymphocytes in the blood due to physical activity can be defined as one of the prognostic signs showing the level of adaptation of the body to physical activity.

Key words: qigong, sport, physicaleducation, bloodanalysis, health.

Научная литература не дает однозначныйответ на вопрос об эффективности применения комплекса традиционных упражнений цигун. Поэтому встает вопрос: возможно ли использование показателей анализов крови в качестве оценки влияния данного метода на здоровье человека?

В китайской философии цигун описывается как целостная система, предназначенная для достижения здоровья методом дыхательных упражнений и медитативных практик. Цигун является истоком китайской народной медицины и делится на внутренний и внешний типы: внутренний цигун - теоретическое понимание применения способа дыхания, внутренний цигун - практическое использование метода и управление дыханием.

Способность человеческой крови приспособиться к нагрузкам подтверждается ее структурным изменением, по которому становится возможным определить функциональную устойчивость системы организма и выявить показатель адаптационной мобильности. Стоит учесть, что функциональная устойчивость напрямую связана со спецификой влияющих на человеческий организм факторов: пол, возраст, состояние здоровья и степень реактивности организма. Не менее важен стаж и вид занятий физической культурой $[5,6]$.

Проявление устойчивых изменений, возникающих в результате выполнения регулярных физических упражнений есть результат биохимических и физиологических сдвигов в системе организма. Подобные сдвиги находят свое отражение в работе внутренних органов и систем крови.

Цель исследования состояла в выявлении факторов положительного воздействия на здоровье студентов УГНТУ, посещающих учебные занятия при использовании в учебном процессе элементов гимнастики цигун.
Методика и организация исследования. В исследовании приняли участие 619 студентов Уфимского государственного нефтяного технического университета. Средний возраст равняется 19-21 годам. Студенты основной медицинской группы, 550 человек из экспериментальных групп и 69 из контрольных групп, без противопоказаний. Допущенные до занятий с предварительным предоставлением анализов крови, для формирования чистоты эксперимента.

Примечательно то, что в кардио-силовых тренировках был применен метод, где система упражнений цигун повторялась после каждой физической нагрузки: бег 10 мин, легкоатлетический беговой комплекс, 10 приседаний с ускорением 30 метров, 10 выпадов с ускорением 30 метров, 5 прыжков с ускорением 30 метров, 5, 6, 7, 9 и 10 отжиманий с интервалом в одну минуту при оздоровительной нагрузке ЧСС 130 уд. в мин и дыханием (16 вдохов, 16 выдохов). После каждой серии нагрузки применялась восстановительная методика цигун.

Комплекс цигун включает в себя дыхание животом (4 вдоха, 4 выдоха) - это естественное дыхание, когда на вдохе живот расширяется, а на выдохе сжимается. Используется в оздоровительном или мягком цигун. Восстановление ЧСС до 100 уд. в мин замерялось секундомером и тонометром.

Контрольные группы делали физическую нагрузку без комплекса цигун.

Исследование каждого студента проводится по результатам двух анализов крови: до начала применения комбинированного комплекса занятий и по окончанию.

Результаты исследования и их обсуждение. Ниже представлены результаты изменения показателей анализов крови студентов. 
Таблица. Результаты анализов крови до и после прохождения физических занятий с промежуточным применением системы дыхания по методике цигун

\begin{tabular}{|l|c|c|c|c|c|}
\hline \multirow{2}{*}{ Средний показатель } & \multicolumn{2}{|c|}{$\begin{array}{c}\text { Дата исследования } \\
\text { экспериментальнй гр. }\end{array}$} & \multicolumn{2}{|c|}{$\begin{array}{c}\text { Дата следования } \\
\text { контрольной гр. }\end{array}$} & \multirow{2}{*}{ Норма* } \\
\cline { 2 - 5 } & $\mathbf{2 1 . 0 9 . 2 0 1 9}$ & $\mathbf{2 0 . 0 2 . 2 0 2 0}$ & $\mathbf{2 1 . 0 9 . 2 0 1 9}$ & $\mathbf{2 0 . 0 2 . 2 0 2 0}$ & \\
\hline Гемоглобин, г/дл & 13,9 & 14,6 & 13.8 & 14.0 & $13-16$ \\
\hline Эритроциты, фл & 4,21 & 4,75 & 4.20 & 4.21 & $4,0-5,0$ \\
\hline Лейкоциты,10^9/л & 7,09 & 6,58 & 7.00 & 7.05 & $4,5-9,0$ \\
\hline Тромбоциты,10^9/л & 252,8 & 277,3 & 255.0 & 260.0 & $180-320$ \\
\hline СОЭ, мм/ч & 8,4 & 6,1 & 8.2 & 8.0 & до 15 \\
\hline
\end{tabular}

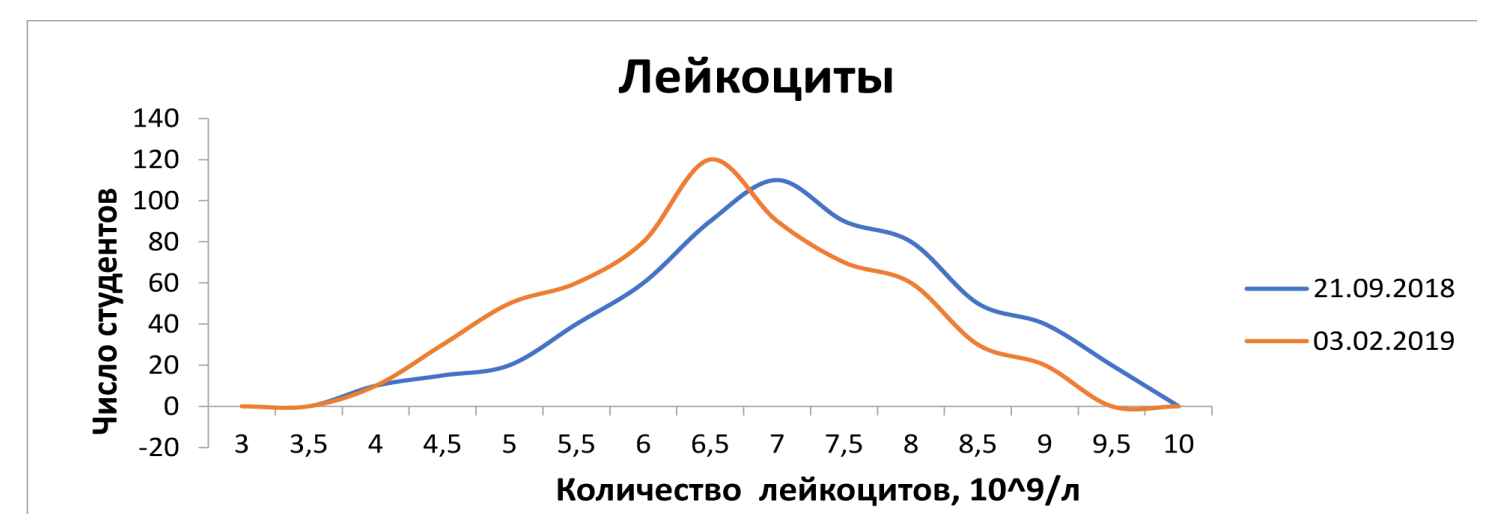

Рисунок 1. Динамика показателей лейкоцитов. Понижение на 7,19 \%, с 7,09 до 6,58

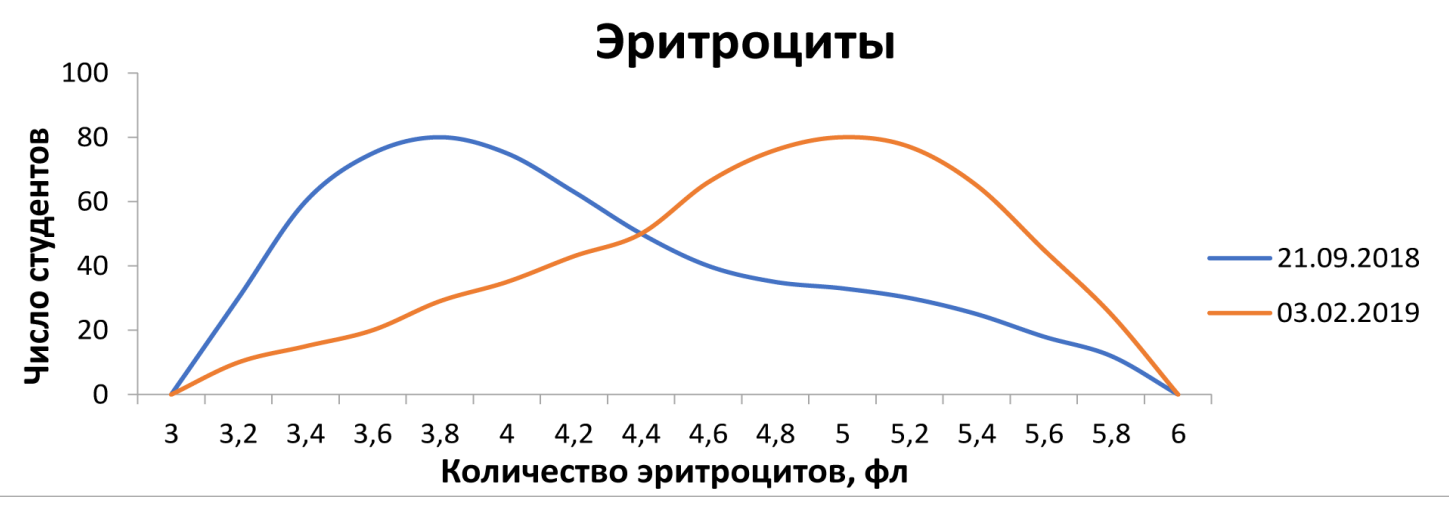

Рисунок 2. Динамика показателей эритроцитов. Увеличение на 12,8 \%, с величины 4,21 до 4,75



Рисунок 3. Динамика показателей гемоглобина. Увеличение на 5 \% концентрации гемоглобина, с показателя 13,9 до 14,6, что увеличило кислородную емкость крови 


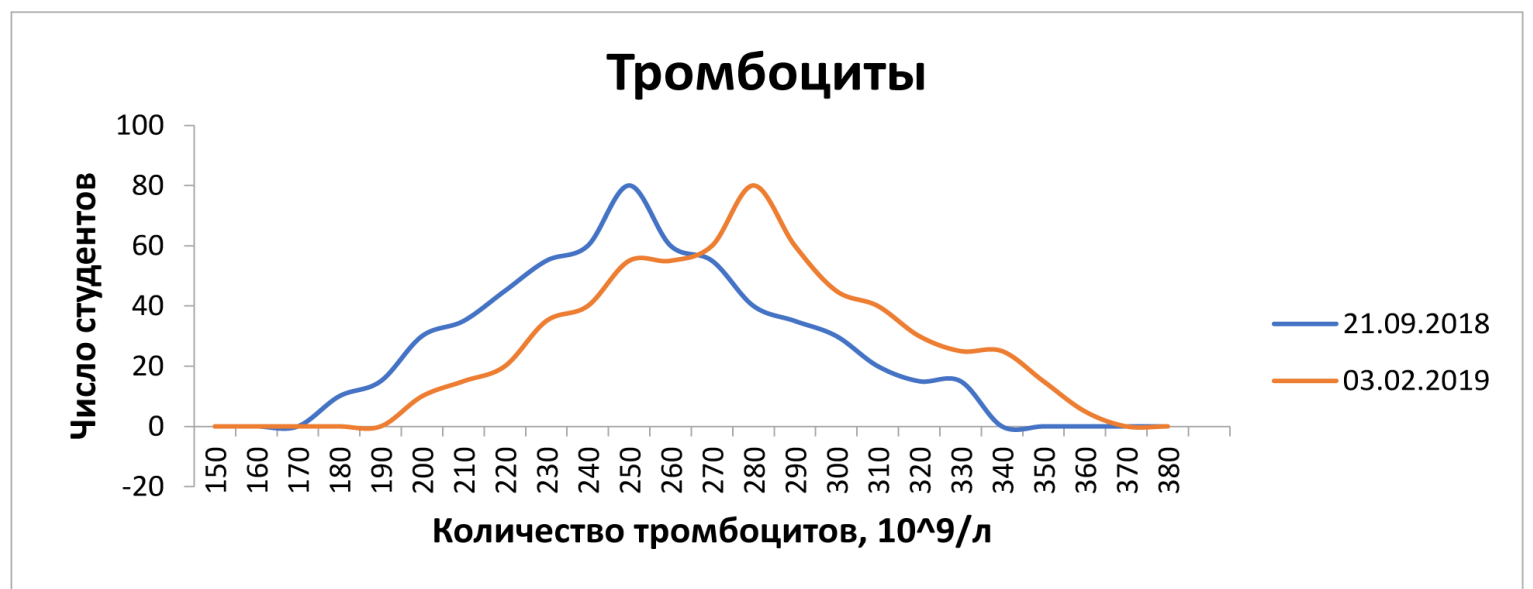

Рисунок 4. Динамика показателей тромбоцитов. Увеличение на 9\%, с величины 258,8 до 277,3. Повышение тромбоцитов в пределах нормы явилось фактором физической нагрузки

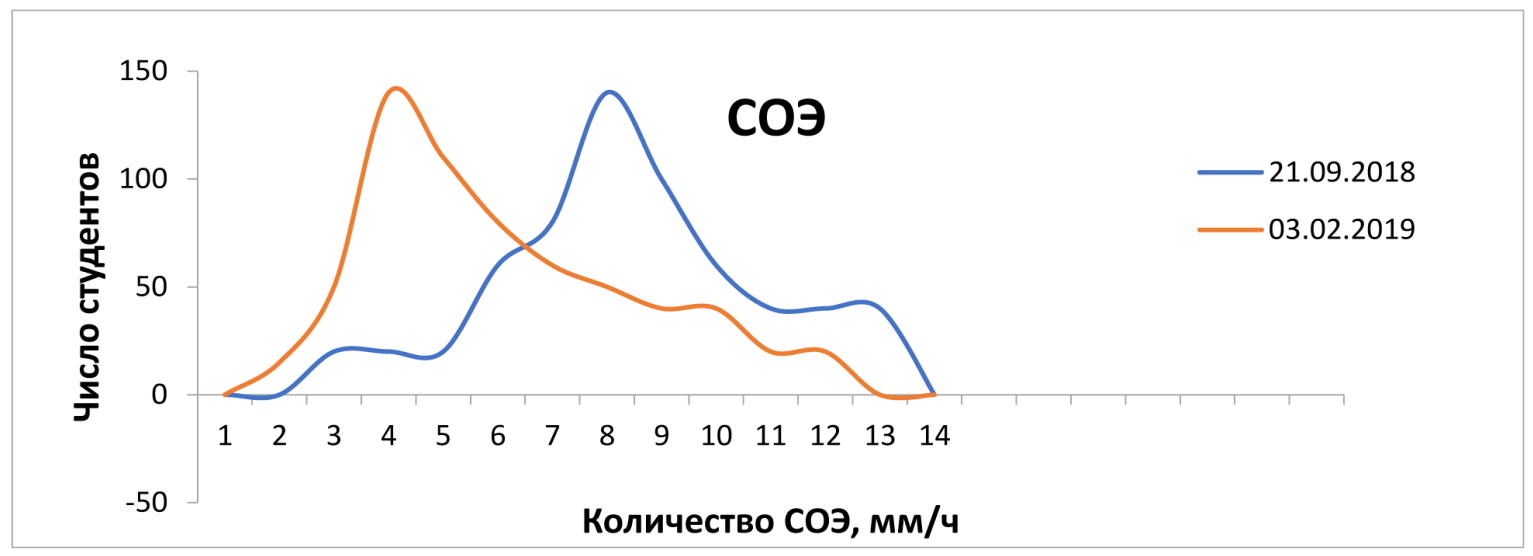

Рисунок 5. Динамика показателей СОЭ. Понижение СОЭ на 27 \%, с 8,4 до 6,4 благодаря увеличению уровня эритроцитов на 12,8 \%, увеличению вязкости крови, что способствовало изменению скорости разделения на плазму и эритроциты

Оценка изменения анализов крови до прохождения комплекса физических упражнений с системой дыхания по методике цигун показала, что в среднем концентрация гемоглобина в крови равна 13,9 г/дл, содержание эритроцитов в крови - 4,21 фл, лейкоцитов - 7,09 10^9/л. Все показатели находятся в пределах физиологической нормы. Наибольшая разница после года занятий данной методикой наблюдается в изменении числа эритроцитов - 4,75 фл ( $\uparrow$ на 12,8 \%) и лейкоцитов - 6,5810^9/л (на 7,19 \%). В процессе тренировки выносливости студентов время жизни их эритроцитов не уменьшается, а наблюдаемая тенденция снижения лейкоцитов в анализах крови вызвана перераспределением этих клеток в кровеносное русло.

В результате систематических занятий физическим воспитанием с совместным при- менением упражнений цигун количество эритроцитов и уровень гемоглобина в крови выросли. Следовательно, повысилась кислородная емкость крови, а вместе с этим и способность организма к сопротивлению инфекционным и простудным заболеваниям, благодаря увеличению активности лейкоцитов. Эритроциты служат переносчиками кислорода, благодаря увеличению их в количественном масштабе кровь может работать с большим количеством кислорода. Также у студентов, подвергающихся регулярной нагрузке, эритроциты образуются активнее, но с уменьшенной продолжительностью жизни. Молодые эритроциты имеют повышенную метаболическую активность, а связь гемоглобин - кислород в тканях - пониженную прочность. В результате можно сделать вывод, что у тренированных студентов кислород легче взаимодействует с тканями, что 
является необходимостью при занятиях тяжелыми и интенсивными тренировками со студентами экспериментальных групп. В контрольной группе уровень гемоглобина остался на прежнем уровне.

Увеличение уровня гемоглобина повышает количество транспортируемого тканям кислорода. Возможность клетки переносить кислород влияет на ее производительность.

Гематокрит, он же объем красных кровяных клеток в крови, определяет способность крови переносить кислород. Больший показатель гематокрита указывает на увеличение вязкости крови, которое может привести к нарушениям работы сердечно-сосудистой системы.

СОЭ (скорость оседания эритроцитов) снизилась из-за увеличения в крови количества эритроцитов, увеличения вязкости крови. Следовательно, кровь стала медленнее разделяться на плазму и эритроциты.

О приспособительной реакции организма по результатам анализов крови к физической нагрузке говорит увеличение содержания гемоглобина и количества форменных элементов крови.

По таблице можно наблюдать, как в результате физических занятий концентрация гемоглобина в крови увеличилась более чем на $5 \%$, вследствие этого произошло увеличение и кислородной емкости крови. Показатели количества лейкоцитов в крови не превысили верхней границы нормы. Можно утверждать отсутствие мгновенного лейкоцитоза. Повышение уровня тромбоцитов на $9 \%$ с показателя 258 до 277,3 в пределах нормы является следствием проведения с учащимися физических нагрузок. У 550 человек экспериментальных групп выявлены эти улучшения. У 69 человек из контрольной группы показатели крови на прежнем уровне и незначительно изменились. С анализами, превышающими нормы содержания тромбоцитов, есть опасность поднять давление. С более низкими показателями тромбоцитов, ниже нормы, при занятиях можно вызвать кровотечение и понижение давления.

\section{Выводы}

В результате исследования используемой методики проведения учебных занятий с 550 студентами экспериментальной группы выявлено ее значительное влияние на здоровье обучающихся, что подтверждается улучшением общего состояния и ряда показателей медицинских анализов. У 69 студентов контрольных групп изменений показателей при тех же нагрузках не произошло. Доказано, что у студентов УГНТУ под совокупным воздействием системы дыхания по методике цигун с занятиями физической культурой происходят выраженные изменения в составе кровеносной системы.

Результат, который мы наблюдаем, указывает на наличие стабилизирующего эффекта регулирования уровня показателей анализов кровеносной системы. Иначе говоря, проделанная работа подтверждает свой первоначальный вложенный в нее смысл, а именно достижение и сохранение здоровья человека. Наблюдаемый результат можно объяснить зависимостью вязкости и кислотности крови, как жестких констант организма, от концентрации эритроцитов и продуктов окисления.

Наибольшее изменение произошло у показателя СОЭ, его количество упало на 27 \% в экспериментальных группах. В контрольных группах СОЭ не понизилась, что свидетельствует, что обычная физическая культура менее эффективна для повышения иммунитета. Значения концентрации эритроцита, гемоглобина и тромбоцитов увеличились, а СОЭ и лейкоцитов - уменьшились, при этом содержание лейкоцитов, эритроцитов и тромбоцитов не превысило границ нормы.

Наличие хорошо выраженного эритроцитоза и увеличение вариабельности количества тромбоцитов в кровеносной системе позволяют использовать данные показатели в качестве одного из возможных морфологических индикаторов реактивности периферической крови, что дает возможность давать оценку состояния здоровья по биохимическому анализу. 


\section{Список литературы}

1. Бочкарева А.А., Лисова И.М., Джандарова Т.И. Влияние физических нагрузок на изменения суточной динамики клеток крови // БМИК. - 2011. - № 7. - С. 18-28.

2. Волков Н.И. Энергетический обмен и работоспособность человека в условиях напряженной мышечной деятельности: автореф. дис. ... канд. пед. наук. - М., 1969. $18 \mathrm{c}$.

3. Горизонтов П.Д. Система крови как основа резистентности и адаптации организма // Физиологический журнал СССР. 1981. - Вып. 27 (3). - С. 317-321.

4. Хабибулина И.Р., Румянцева Э.Р. Влияние физической нагрузки на различные звенья системы крови у фехтовальщиков // Вестник ЮУрГУ. Сер. Образование, здравоохранение, физическая культура. - 2006. № 3-1. - С. 46-54.

5. Александров Н.П. Изменения в системе красной крови человека (эритроне) при адаптации к новым условиям // Здоровье. - 2010. - № 1. - С. 16-25.

6. Ефименко А.М., Ширяев В.В., Толкачева Н.В. Особенности морфологического состава крови, функциональных свойств клеток и белков сыворотки крови в различные периоды тренировочного процесса стайеров // Спортивная медицина. - 1978. - С. 187-188.

\section{References}

1. The influence of physical activity on changes in the daily dynamics of blood cells. // BMIK. - 2011. - № 7. - P. 18-28.

2. Volkov N.I. Energy metabolism and human performance under conditions of intense muscul aractivity: author. dis. ... Cand. ped. sciences. - M., 1969. - 18 p.

3. Gorizontov P.D. The blood system as the basis of resistance and adaptation of the organism // Physiological journal of the USSR. - 1981. Vol. 27 (3). - P. 317-321.

4. Khabibulina I.R., Rumyantseva E.R. The influence of physical activity on various links of the blood system in fencers // Bulletin of SUSU. Ser. Education. healthcare, physical education. - 2006. - № 3-1. - P. 46-54.

5. Alexandrov N.P. Changes in the human red blood system (erythrone) during adaptation to new conditions // Health. - 2010. - № 1. P. 16-25.

6. Jefimenko A.M., Shiryaev V.V., Tolkacheva N.V. Features of the morphological composition of blood, functional properties of cells and proteins of blood serum in different periods of the training process of stayers // Sports medicine. - 1978. - P. 187-188. 